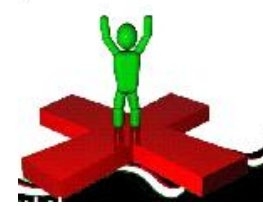

DOI : 10.15740/HAS/IJMS/7.1and2/55-57 Volume 7|Issue 1\&2|October, 2014|55-57

International Journal of Medical Sciences

RESEARCH PAPER

e ISSN-0976-7932 | Visit us - www.researchjournal.co.in

\title{
Effectiveness of health improvement programme for obesity - a cross-sectional study
}

\section{HINA K. BHADANIYA AND DAXA J. JOTANGIYA}

See end of the paper for authors' affiliation

Correspondence to : HINA K. BHADANIYA M.V.M. Science and Home Science College, RAJKOT (RAJASTHAN) INDIA

Email:

heena_hs2011@yahoo.in

\section{KEY WORDS :}

Obesity, Health, Height, Weight, Fat

\begin{abstract}
ACross-sectional study was carried out to estimate the prevalence of overweight and obesity, and identify lifestyle factors associated with obesity among men residing in Rajkot City and a project was designed to improve overall health of overweight/obese men by introduction of corrective and nutritious diet and physical exercise. Total 246 men joined this programme. Pre-test and post-test data showed decrease in weight, abdomen/waist circumference and pulse-rate and increase in hemoglobin percentage have been found after implementation of this programme which indicates that the Health Improvement Programme was effective on obesity. Effectiveness of the programme was very on each subject. Those who were punctual, co-operative and health conscious availed more benefit from this programme. Along with weight reducing most of the health related problems related to obesity like indigestion, overeating, gastric trouble, constipation, fatigue, breathlessness and various body aches were solved or lessened.
\end{abstract}

How to cite this paper : Bhadaniya, Hina K. and Jotangiya, Daxa J. (2014). Effectiveness of health improvement programme for obesity - a cross-sectional study. Internat. J. Med. Sci., 7(1\&2) : 55-57. 